\title{
WORK-RELATED ATTITUDES OF CZECH GENERATION Z: INTERNATIONAL COMPARISON
}

\section{Kubátová, J.}

The goal of this article is to present work-related attitudes of a sample of Czech Generation Z and their comparison to the results of an international research study. Currently, there are three important trends influencing the labor market: (1) the origin and development of a ubiquitous working environment, (2) the thriving of coworking centers, and (3) Generation Z's entering the labor market. Instead of traditional jobs, the bearers of human capital tend to choose independent work in an online environment, and often work in coworking centers. Using self-determination theory, we substantiate why they thrive better this way. Based on the results of an international research project focused on work attitudes among Generation $Z$ and the results of a replication study we carried out in the Czech Republic, we attest that members of Generation Z may prefer independent virtual work in coworking centers, too. The total amount of available human capital, the lack of which is pointed out by companies, may grow thanks to new ways of working. Companies, which can use human capital of independent workers, gain a competitive advantage.

Keywords: Generation Z; ubiquitous working environment; coworking; human capital JEL Classification: M100

\section{Introduction}

Current information and communication technologies (ICT) are significantly changing activities of companies, including where and how people work and communicate (Cascio and Montealegre, 2016). Brynjolfsson and McAfee (2014) prove that technological progress significantly changes demand for many types of work. On the global market, demand for highly qualified work exceeds the offer (PwC, 2016). Bradley et al. (2015) point out that ensuring the necessary human capital is one of the most significant tasks of company managements. In this environment, a large part of knowledge work may be performed and delivered online. An online labor market is being developed on the Internet, and a growing number of professionals (Moravec et al., 2013) prefer independent work in this environment to traditional jobs in a company. In response to the feeling of social isolation of virtual workers, coworking centers have started to originate in the past few decades (Spinuzzi, 2012), in which workers can rent work stations (desks/offices) and perform their independent work, while being a part of a community at the same time. We suggest that self-determination theory (Ryan and Deci, 2000) explains why workers in coworking centers are more satisfied than if they had a traditional job. Currently, Generation $\mathrm{Z}$ is entering the labor market. Every generation has certain specific values, needs and attitudes, which also concerns work and the work environment (Lyons and Kuron, 2014). In 2014, Schawbel published results of an international research study dealing with work-related attitudes of Generation Z. This research did not include the Czech Republic. In order to get to know the work-related attitudes of the Czech Generation Z, we carried out a replication study in this country. 
The goal of this article is to present and analyze the work-related attitudes of a sample of Czech Generation $Z$ which resulted from the replication study based on Schawbel's (2014) research study and their comparison to the results of Schawbel's study. We suggest that the work attitudes of Generation $\mathrm{Z}$ may lead to choosing independent work in coworking centers. Firms can be recommended that they start using human capital of independent workers effectively, and prepare for Generation Z's entering the labor market.

\section{Conceptual Framework}

The theoretical part of the article is based on a literature review. The main contribution of the theoretical part lies in the application of self-determination theory (Ryan and Deci, 2000) on the work attitudes of the clients of coworking centers. The work-related attitudes of a sample of Czech Generation $\mathrm{Z}$ are presented in the practical part, and are compared to the results of Schawbel's (2014) international research study. Sociologically speaking (Ryder, 1965), a generation means a set of individuals born in the same time interval and/or those who experienced the same event. Every generation creates its own opinions, views, and values, which are reflected also in the attitudes of its members toward work and professional careers. There is no unanimous agreement as to specifying the time when Generation $\mathrm{Z}$ members were born. In general, Generation Z are people born between 1995 and 2010 (Schawbel, 2014; McCrindle, 2014).

Schawbel's research was carried out in ten countries (USA, Brazil, Canada, China, Germany, India, South Africa, Sweden, Turkey, and Great Britain) among two thousand Generation Z members. In the Czech Republic, a purposive sample consisting of 213 respondents was examined; this number of respondents for a single country is comparable to Schawbel's research. The Czech respondents were the students of the first year of economic studies at the Faculty of Arts, at Palacky University in Olomouc (95 respondents), and the students of the last study year at a college preparation school in Ostrava Hrabová (118 respondents). The research was carried out in 2015, thus these respondents were the oldest members of Generation $\mathrm{Z}$ and had to think about their future professional career. As they were students of the university or a college preparation school, it was very likely that they would become knowledge workers. This is important because only knowledge work can be delivered online. There are coworking centers in both of these cities; however, the respondents were not officially informed of their existence before the research study. The respondents were asked to fill out a paper-pencil questionnaire with multiple choice questions. To analyze the results of the research, relative frequencies of answers were used. As the question of one's preferred workplace is crucial, we used the $\mathrm{Z}$ score test to find out if the differences between the Czech and international samples were significant. We also conducted an overall comparison of the pattern of the answers between Schawbel's and the Czech samples using the Chi-square test.

Changes in work environment and the corresponding social and economic phenomena are reflected in academic literature. The work attitudes of Generation $\mathrm{Z}$ members have not been paid much attention yet. However, trends being analyzed are dealt with separately. The contribution of this article lies in the synthesis of these trends, which gives a more complex view of the problem of lack of human capital in companies, and its possible solution, which is using independent work. 


\section{The Origins of a Ubiquitous Working Environment, Freelancers and Coworking Centers}

According to Bradley et al. (2015), the development of mankind can be divided into three eras based on technologies used: agricultural, industrial, and the current one - digital. The digital era is based on ICT. As these can be used regardless of place and time borders and geographical distances lose their importance, and a new economic space is being created. Today's computer technologies are virtually ubiquitous. This gives rise to a ubiquitous working environment, which enables various new ways of work. Sundarajan (2016) proves that this environment supports entrepreneurship and cooperation and it gives rise to new business models based on the idea of a shared economy, for example companies such as Airbnb or Uber. Nevertheless, companies have long-term problems staffing work positions more demanding in terms of workers' skills (ManPower, 2015). Among the Central European countries, this problem is considered the most burning by Hungary where $47 \%$ of employers mentioned it, followed by Germany with $46 \%$, Poland $41 \%$, Austria 39\%, Slovakia 28\%, Slovenia 24\%, and the Czech Republic with 18\% of employers mentioned it.

A ubiquitous working environment enables new forms of work, and it is also a place where companies may find the necessary human capital. An online labor market is being developed on the Internet. According to J. J. Horton (2010), the online labor market is a market where (1) labor is exchanged for money, (2) the product of that labor is delivered "over a wire" and (3) the allocation of labor and money is determined by a collection of buyers and sellers operating within a price system. The online labor market appeals to an increasing number of people on the side of work offer, thus gradually increasing the number of experts from various fields, who opt for independent work in an online environment instead of a traditional job with an employment contract. These independent professionals have assumed the globally recognized term freelancers. According to Moravec et al. (2013), freelancers will represent up to $45 \%$ of Western civilization's workforce by 2020, and this trend will continue in the future.

Together with the development of technologies, there are also changes in the ways of virtual work. According to Johns and Gratton (2013), we are now in the third wave of virtual work. The first wave is connected to the beginnings of virtualization of knowledge work in the 1980s when email started to be used at work. The second wave started in the beginning of the $21^{\text {st }}$ century. Virtual work started to spread and companies set up virtual teams, i.e. teams whose members were in touch only or mostly online. This way of working brought many advantages, e.g. the possibility to use human capital of workers located far away, reduction of running costs, but there were also disadvantages of this way of working. The most significant were feelings of isolation and a lack of social contact of virtual workers and problems related to ineffective sharing of knowledge while using online communication only. Coworking centers started appearing in response to these problems. Their development is connected to the current third wave of virtual work. According to Spreitzer (2015), coworking centers are membership-based workspaces where diverse groups of freelancers, remote workers, and other independent professionals work together in a shared, communal setting. In a coworking center, it is possible to rent a work station equipped with all the necessary technology, and it often also includes other services such as looking after children. 
Working in coworking centers is increasingly popular, which is proven by the development of the number of existing coworking centers and their clients (Deskmag, 2014; Deskmag, 2015; Deskmag, 2016). In 2010, there were around 600 coworking centers in the world, almost 6,000 in 2014, and there are expected to be around 37,000 by 2018. The number of clients of coworking centers is growing, too. In 2010, there were 21,000, and by 2018 coworking centers are expected to have almost 2.4 million clients.

\section{Thriving in Coworking Spaces}

Comparing employees of traditional companies to workers from coworking centers has shown that clients of coworking centers thrive significantly better. According to Portah et al. (2012), thriving is a psychological state composed of the joint experience of vitality and learning. When people thrive, their performance is very good and they are also in good health.

One of the reasons is that workers in coworking centers perceive their work as meaningful. This is also possible thanks to the fact that they choose their projects themselves. Another reason is the culture of coworking centers where collaboration, community, participation and learning are shared values. Mutual help is a common thing, and at the same time, there is no direct competition or internal politics. Workers also have much greater job control as they can organize their working time totally according to their needs. On the other hand, community life in a coworking center helps them keep a motivating routine and discipline. A fourth reason for greater thriving is the feeling of relatedness with their community. Relations with other clients are some of the most significant reasons why people do not work from home but from a coworking center.

The above reasons (meaningful work, values and internal culture, job control and relatedness with their community) correspond well to the theory of self-determination (Ryan and Deci, 2000). According to this theory, self-motivation and well-being are achieved if the need for autonomy, competence and relatedness has been satisfied. Autonomy is connected to the need to independently control our own lives, competence is connected to the need for assurance of our own good performance, and the need for relatedness is connected to the feeling of relatedness with others. Satisfying these needs is closely influenced by the environment, in which an individual lives. It can be assumed that the environment of coworking centers does satisfy these needs. The needs for autonomy and competence may be satisfied by choosing meaningful work which the workers know that they can do it well, and the possibilities to organize their own work time. The need for relatedness is satisfied by relatedness with the community of a particular coworking center.

\section{Work Attitudes of Generation Z}

The results of the above-mentioned research studies are presented below. The first question focused on the plans of the respondents: "Once you have completed formal education, would you rather be an employee or entrepreneur?" According to Schawbel's international study, $17 \%$ of Generation $\mathrm{Z}$ members are planning to become entrepreneurs, compared to $24 \%$ among Czech respondents. According to a research study carried out by the company ODesk (2013), young people have a new attitude toward entrepreneurship. In their opinion, entrepreneurship is based on innovative thinking, creativity, and finding one's own way. They claim it is not a question of setting up and developing their own business, but using their own human capital in the sense of active searching for 
entrepreneurial opportunities. In this sense, freelancers are considered to be entrepreneurs, too.

The next question concerned their preferred work environment: "What kind of work environment do you prefer?" Table 1 shows the structure of the answers as well as the results of the statistical testing conducted to find out if there is a difference in relative frequencies of each of the preferred workplaces between Schawbel's and the Czech samples of respondents.

Table 1 | Type of workplace preferred by Generation Z

\begin{tabular}{|l|c|c|c|c|}
\hline & $\begin{array}{c}\text { Schawbel's } \\
\text { study [\%] }\end{array}$ & Czech study [\%] & Z score & p \\
\hline Corporate office & 28 & 59 & -9.346 & 0.000 \\
\hline Coworking center & 27 & 3 & 7.783 & 0.000 \\
\hline Home office & 19 & 6 & 4.682 & 0.000 \\
\hline No preference & 26 & 32 & -1.861 & 0.063 \\
\hline
\end{tabular}

Source: Schawbel (2014) and author

We have concluded that the Czech sample prefers corporate office more than the Schawbel's one does $(p=0.000)$. Coworking centers were significantly less preferred in the Czech sample $(p=0.000)$ and so were home offices $(p=0.000)$. The proportion of Generation $\mathrm{Z}$ respondents without any preference is, however, not significantly different in the two samples $(\mathrm{p}=0.063)$. Both samples can be considered significantly different from each other (chi-square $=126.4767, \mathrm{p}<0.0001$ ). Since the proportion of Generation $\mathrm{Z}$ respondents without any preference does not differ between the samples, we can conclude that those who do prefer some type of workplace have significantly different preferences in the Czech sample than in Schawbel's sample.

Another question focused on work communication: "What way of communication with your colleagues and manager do you consider the most effective?" Table 2 shows the structure of their answers:

Table 2 | Preferred way of work communication of Generation Z

\begin{tabular}{|l|c|c|}
\hline & Schawbel's study [\%] & Czech study [\%] \\
\hline In person & 50 & 91 \\
\hline Email & 16 & 2 \\
\hline Instant messaging & 11 & 2 \\
\hline Phone & 9 & 2 \\
\hline Social networking & 8 & 2 \\
\hline Videoconferencing (Skype) & 6 & 1 \\
\hline
\end{tabular}

Source: Schawbel (2014) and author 
Whereas half of the international respondents preferred personal communication, it is over $90 \%$ in the Czech Republic. The use of various means of electronic communication is preferred by a low ratio of respondents. However, it is generally well-known that young people do use electronic communication and the Internet. Table 3 shows the structure of answers to the question: "What best use do you have for ICTs for your work?"

Table 3 | Use of ICTs in work environment

\begin{tabular}{|l|c|c|}
\hline & Schawbel's study [\%] & Czech study [\%] \\
\hline Allow me to get answers to my questions faster & 37 & 66 \\
\hline Help me develop my skills & 24 & 15 \\
\hline Let me collaborate on projects more effectively & 20 & 11 \\
\hline Enhance personal relationships with coworkers & 14 & 7 \\
\hline Give me a channel to express myself & 5 & 1 \\
\hline
\end{tabular}

Source: Schawbel (2014) and author

Generation Z uses ICT mostly to seek information; using it for collaboration has a lower priority. This corresponds to the preference of personal communication documented above. In respect to the significance of meeting in person for Generation $\mathrm{Z}$, the following question is important: "What people boost your work performance the most?" Table 4 shows the structure of the answers.

Table 4 | People who boost work performance of Generation Z members

\begin{tabular}{|l|c|c|}
\hline & Schawbel's study [\%] & Czech study [\%] \\
\hline Colleagues willing to work as hard as me & 25 & 33 \\
\hline Close friends & 18 & 16 \\
\hline People who like to collaborate with & 17 & 19 \\
\hline People I socialize with after work & 16 & 5 \\
\hline People whose work is their primary interest & 11 & 10 \\
\hline Competitive co-workers & 9 & 3 \\
\hline People who prefer to work alone & 3 & 2 \\
\hline
\end{tabular}

Source: Schawbel (2014) and author

In this case, the importance of good mutual relations and emphasis on balanced work performance are unanimously demonstrated.

The question: "What type of work diversity do you welcome at your workplace?" was meant to find out what attitudes the respondents had to diversity. More answers were allowed. Table 5 shows the structure of the respondents' answers: 
Table 5 | Type of diversity welcome at the workplace

\begin{tabular}{|l|c|c|}
\hline & Schawbel's study [\%] & Czech study [\%] \\
\hline Fields of specialty & 54 & 79 \\
\hline Genders & 31 & 25 \\
\hline Cultural backgrounds & 28 & 22 \\
\hline Income levels & 22 & 18 \\
\hline Religious beliefs & 18 & 5 \\
\hline Ethnic backgrounds & 17 & 8 \\
\hline
\end{tabular}

Source: Schawbel (2014) and author

Diversity of fields is the most welcome type of preference. This preference was significantly higher in the Czech study than in the international one.

The expectations of managers were established by asking the question: "What is the best thing a manager can do to boost your work performance?" The three most preferred attitudes were the same in both studies: listen to my ideas, mentor me and give me meaningful work.

The last area to be looked into was support elements at the workplace. The structure of answers to the question "What elements at the workplace boost your performance?" is shown in Table 6 . The respondents were allowed to give more answers.

Table 6 | Elements at the workplace which boost the performance of Generation Z

\begin{tabular}{|l|c|c|}
\hline & $\begin{array}{c}\text { Schawbel's study } \\
{[\%]}\end{array}$ & $\begin{array}{c}\text { Czech study } \\
\text { [\%] }\end{array}$ \\
\hline The type of work I do & 65 & 52 \\
\hline The people I work with & 65 & 70 \\
\hline The ability to personalize my space & 38 & 52 \\
\hline The location of the facility/building/office where I work & 36 & 12 \\
\hline $\begin{array}{l}\text { The ability to listen to music/wear headphones while } \\
\text { working }\end{array}$ & 29 & 33 \\
\hline The privacy of the workspace & 27 & 30 \\
\hline The size of the workspace & 27 & 11 \\
\hline
\end{tabular}

Source: Schawbel (2014) and author

From the answers of Generation $\mathrm{Z}$ members, it is clear that the work itself they do and people they collaborate with are the most significant factors of their work performance. For Czech respondents, coworkers are the most significant factor, and the possibility to modify their workplace is important, too. 


\section{Discussion}

In this article, several important trends that have a strong influence on available human capital are presented. And even though there are limitations to the presented research, recent development in the labor market should not be ignored. Based on the results of the Czech replication study, it might seem that Generation $\mathrm{Z}$ here is quite conservative. But it only applies to the particular sample of respondents we dealt with. This sample consisted of the oldest members of Generation $\mathrm{Z}$ in two cities and a considerable part of them were students of economics. The sample in the Czech Republic consisted of Generation $\mathrm{Z}$ representatives with a high potential of becoming knowledge workers. As such, the results presented here cannot be generalized to the whole Generation Z, but remain valid for the part of it that has the potential to do knowledge work and be the clients of coworking centers. The research should be replicated in more regions, across more professions and later among more age groups within Generation Z. Discussions with the respondents after the survey showed that very few of them knew what coworking meant or that there were coworking centers in the Czech Republic. So it would be interesting to examine if there would be any change in their preferred workplaces in case their awareness of coworking increases.

\section{Conclusion and Managerial Implications}

The current work environment is changing dramatically. Routine work is being replaced by technologies and human capital finds use especially in knowledge work. This can be performed in a virtual environment thanks to available ICT. A growing number of workers are deciding to do independent work which they find in the online labor market, but due to their need for social contacts they work from coworking centers. Generation $\mathrm{Z}$ members who are now entering the labor market, strongly prefer personal communication, and use technologies mainly to seek information, even if some of them also find ICT useful for collaboration. These members of Generation $\mathrm{Z}$ consider people from their work environment as very important. They especially appreciate if they are experts in various fields. From the requests of Generation $\mathrm{Z}$ toward managers ensues the need for autonomy. The fact that they want their superiors to also be their mentors clearly suggests a desire for competence. For these members of Generation $\mathrm{Z}$ the most important elements of work performance are the work they do itself, and the people they collaborate with. These elements may be fulfilled by choosing independent work which is, according to young generations, a way of entrepreneurship with their own human capital. Around a fifth of Generation $Z$ members are planning to become entrepreneurs, and over a quarter of Generation $\mathrm{Z}$ respondents in the international research study mentioned they would like to work in a coworking center. This also means that some future employees would prefer a coworking center to another workplace. However, in the Czech Republic, respondents significantly preferred corporate office. This only applies to this particular sample of respondents and further research is necessary. In general, we can expect that a part of Generation $\mathrm{Z}$ will prefer independent work from coworking centers to having traditional jobs because it will satisfy their needs for autonomy, competence and relationships.

The role of management and managers is dramatically changing in the current technological and social environment. Dewhurst and Willmott (2014) emphasize that using 
the full potential of this environment will require new models of working in organizations. As we proved, this includes the ability to use human capital from new sources such as online talent markets and coworking centers where a lot of it is moving.

\section{References}

Bradley, S., Madnick, S., \& Kim, C. (2015) Digital Business. Chicago: Chicago Business Press.

Brynjolfsson, E., \& McAfee, A. (2014). The second machine age: work, progress, and prosperity in a time of brilliant technologies. New York: WW Norton \& Company.

Cascio, W. F., \& Montealegre, R. (2016). How Technology Is Changing Work and Organizations. Annual Review of Organizational Psychology and Organizational Behavior, 3(1), 349-375.

Deskmag (2014). Deskmag Survey 2014. Retrieved December 8, 2014 from https://www. youtube.com/watch?v=hutCeXQ9Z6Y.

Deskmag (2015), First Results of the New Global Coworking Survey.

Retrieved November 25, 2015 from http://www.deskmag.com/en/

first-results-of-the-new-global-coworking-survey-2015-16.

Deskmag (2016). 2016 Coworking Forecast. Retrieved February 5, 2016 from http://www. deskmag.com/en/2016-forecast-global-coworking-survey-results.

Dewhurst, M, \& Willmott, P. (2014). Manager and machine: the new leadership equation. McKinsey Quarterly, Sept. 2014. Retrieved from http://www.mckinsey.com/insights/ leading_in_the_21st_century/manager_and_machine.

European Commission (2014). Statistical Data on Women Entrepreneurs in Europe. Retrieved February 10, 2015 from http://ec.europa.eu/growth/tools-databases/newsroom/cf/ itemdetail.cfm?item_id=7992.

Horton, J. J. (2010). Online labor markets. In Saberi, A. (Ed), Internet and Network Economics (pp. 501-522). Berlin, Heidelberg: Springer.

Johns, T., \& Gratton, L. (2013). The third wave of virtual work. Harvard Business Review, 91(1), 66-73.

Lyons, S., \& Kuron, L. (2014). Generational differences in the workplace: A review of the evidence and directions for future research. Journal of Organizational Behavior, 35(1), 139-157.

ManPower (2015). Talent Shortage Survey 2015. Retrieved December 18, 2015 from http://www.manpowergroup.com/wps/wcm/connect/manpowergroup-en/home/ thought-leadership/research-insights/talent-shortage-2015.

McCrindle, M. (2014). The ABC of XYZ: Understanding the Global Generations. McCrindle: Kindle Edition.

Moravec, J. W. et al. (2013). Knowmad Society. Minneapolis: Education Futures.

ODesk (2013). Millennials and the future of work. Retrieved November 28, 2014 from https:// www.odesk.com/info/spring2013onlineworksurvey.

Porath, C., Spreitzer, G., Gibson, C., \& Garnett, F. G. (2012). Thriving at work: Toward its measurement, construct validation, and theoretical refinement. Journal of Organizational Behavior, 33(2), 250-275.

PwC (2016). 19th Annual Global CEO Survey. Redefining Business in a Changing World. Retrieved January 25, 2016 from http://www.pwc.com/gx/en/ceo-agenda/ceosurvey/2016.html.

Ryan, R. M., \& Deci, E. L. (2000). Self-determination theory and the facilitation of intrinsic motivation, social development, and well-being. American Psychologist, 55(1), 68-78. 
Ryder, N. B. (1965). The Cohort as a Study in the Concept of Social Change. American Sociological Review, 30(6), 843-861.

Schawbel, D. (2014). Generation Z. Understanding the Next Generation of Worker. Retrieved November 10, 2014 from http://millennialbranding.com/2014/ geny-genz-global-workplace-expectations-study.

Spinuzzi, C. (2012). Working Alone Together: Coworking as Emergent Collaborative Activity. Journal of Business and Technical Communication, 26(4), 399-441.

Spreitzer, G., Bacevice, P., \& Garrett, L. (2015). Why People Thrive in Coworking Spaces. Harvard Business Review, 93(7), 28-30.

Sundarajan, A. (2016). Crowd-Based Capitalism? Empowering Entrepreneurs in the Sharing Economy. MIT Sloan Management Review. Retrieved April 4, 2016 from http://sloanreview.mit.edu/article/ crowd-based-capitalism-empowering-entrepreneurs-in-the-sharing-economy/.

The Economist (2015). Rise of the machines: Artificial intelligence scares people - excessively so. The Economist. Retrieved December 2, 2016 from www.economist.com/news/ briefing/21650526-artificial-intelligence-scares-peopleexcessively-so-rise-machines.

\section{Author}

\section{Jaroslava Kubátová, Ph.D.}

Associate Professor

Faculty of Arts, Palacky University in Olomouc, Czech Republic

jaroslava.kubatova@upol.cz

This paper is a research output of the project IGA_FF_2015_014 Continuities and Discontinuities of Economy and Management in the Past and Present. 